\title{
EL VIRUS DE LA DIARREA VIRAL EN BOVINOS CRIOLLOS DE LA PROVINCIA DE MELGAR, PUNO
}

\author{
Bovine Viral Diarrea Virus in Criollo Cattle of the Province of \\ Melgar, Puno
}

Richard Quispe Q. ${ }^{1}$, Alberto Ccama S. ${ }^{2}$, Hermelinda Rivera G. ${ }^{1,3}$ y Mariluz Araínga R. ${ }^{1}$

\section{RESUMEN}

El estudio tuvo por objetivo determinar la seroprevalencia del virus de la diarrea viral (VDVB) en bovinos criollos de la provincia de Melgar, Puno. Se obtuvieron muestras de sangre de bovinos $(n=347)$ machos y hembras mayores a seis meses de edad para la detección de anticuerpos neutralizantes mediante la prueba de neutralización viral. El $48.7 \pm 0.1 \%$ (166/347) de los animales presentó anticuerpos contra el VDVB. No se detectaron animales portadores del virus. Anticuerpos fueron detectados en animales de todos los distritos con prevalencias entre 15.7 a $94.1 \%$. Los títulos de anticuerpos estuvieron en un rango de 2 a >256, indicando que el VDVB está ampliamente difundido en bovinos de la zona. Las altas prevalencias de anticuerpos evidencian intensa actividad viral; así mismo, los títulos altos indican infecciones recientes y sugieren la existencia de factores que promueven la difusión viral como las ferias ganaderas y la falta de control en el tránsito interno de animales en la zona.

Palabras clave: bovinos criollos, virus, diarrea viral bovina, crianza mixta, anticuerpos, neutralización viral

\section{Abstract}

The prevalence of bovine viral diarrhea virus (BVDV) infection was evaluated in 347 criollo cattle of both sexes and older than 6 months of age in small herds of the province of Melgar, Puno. Serum samples were tested for antibodies against BVDV using the viral neutralization test. The $48.7 \pm 0.1 \%(166 / 347)$ of the samples had antibodies against BVDV. Animals carrying on the virus virus were not detected. Antibodies were detected in all sampled herds and the prevalence varied from 15.7 to $94.1 \%$. Antibodies titers varied from 2 to $>256$, showing that BVDV infection is widespread in the local cattle population, suggesting the presence of factors promoting the viral distribution such livestock fairs and lack of control for animal movements within the region.

Key words : criollo cattle, virus, bovine viral diarrhoea, multi-species breeding, antibodies, viral neutralization

\footnotetext{
${ }^{1}$ Laboratorio de Microbiología y Parasitología Veterinaria, Facultad de Medicina Veterinaria, Universidad Nacional Mayor de San Marcos, Lima

${ }^{2}$ Universidad Nacional del Altiplano, Puno

${ }^{3}$ E-mail: hriverag2005@yahoo.es
} 


\section{INTRODUCCIÓN}

La provincia de Melgar, dentro del departamento de Puno, presenta una notable actividad pecuaria. Tiene una población de 91,710 bovinos de tipo criollo y cruzados con Brown Swiss, constituyendo el $15.3 \%$ de la población total de bovinos de la Región Puno. Los animales son criados en forma extensiva o semi extensiva, alimentados con pasturas naturales y en menor escala con pastos cultivados de alto valor forrajero. $\mathrm{La}$ zona tiene una producción de leche de 10,015 TM/año; y como en todas las zonas altoandinas, el desarrollo de la ganadería se encuentra afectado por la falta de adecuada tecnología de manejo y programas sanitarios que en conjunto repercuten en la producción y productividad (MINAG-OIA, 2003).

La diarrea viral bovina (DVB) es una enfermedad de distribución mundial y endémica en la mayoría de las poblaciones bovinas (Houe, 1995, 1999). Es causado por el virus de la diarrea viral bovina (VDVB), antigénicamente relacionado a los virus de la Peste Porcina Clásica (PPC) y Enfermedad de la Frontera (VEF), donde los tres agentes pertenecen al género pestivirus, familia Flaviviridae (Wengler, 1991). El VDVB posee un biotipo citopatogénico (CP) y otro no citopatogénico (NCP) según su efecto en cultivo celular, pero ambos biotipos ocasionan la misma enfermedad con amplio rango de manifestaciones clínicas, predominando la forma subclínica en el 70-90\% de los casos (Baker, 1995).

La forma aguda se caracteriza por ser leve, pero el animal puede presentar fiebres ligeras, leucopenia, lesiones discretas en la mucosa oronasal y una mayor susceptibilidad a infecciones secundarias. El efecto del virus en el tracto reproductivo tiene impacto económico ya que puede inducir infertilidad temporal, muerte embrionaria, abortos, malformaciones congénitas, y nacidos débiles o con infección persistente, dependiendo del periodo de la gestación, del biotipo y virulen- cia de la cepa viral infectante (McGowan y Kirkland, 1995; Brownlie et al., 1998).

Estudios serológicos realizados en bovinos de las principales cuencas lecheras del Perú muestran que el VDVB está ampliamente difundido, y con prevalencias superiores al 50\% (Contreras et al., 2000; Rivera et al., 2001; Aguilar et al., 2006; Ståhl et al., 2008). A pesar de la importancia socio-económica del ganado bovino de las zonas andinas y la carencia de restricciones con la DVB para el movimiento interno de los bovinos en el país, existe escasa información sobre la prevalencia de la infección en valles interandinos y zonas altoandinas en donde actualmente existe un creciente interés en el desarrollo de la industria lechera. El objetivo del presente estudio fue determinar la seroprevalencia del virus de la diarrea viral en bovinos criollos de los nueve distritos de la provincia de Melgar, Puno.

\section{Materiales y Métodos}

\section{Lugar de Estudio}

La provincia de Melgar está ubicada al noreste de la región de Puno, a una altitud de 3,900 a 4,400 msnm. La ganadería es de tipo mixto con predominancia de bovinos y ovinos, aunque en algunos distritos se tiene camélidos sudamericanos. Los hatos bovinos están constituidos por animales criollos y mejorados con Brown Swiss bajo un sistema de crianza extensivo con pastos naturales y cultivados.

El presente estudio se realizó en bovinos de 70 productores de los distritos de Nuñoa $(\mathrm{n}=8)$, Orurillo $(\mathrm{n}=5)$, Umachiri $(\mathrm{n}=9)$, Santa Rosa ( $n=10)$, Macari ( $n=12)$, Antauta $(n=14)$, Llalli $(n=8)$ y Cupi $(n=4)$ de la provincia de Melgar, Puno.

\section{Tamaño Muestral}

El tamaño de muestra fue determinado mediante el método no paramétrico de 
muestreo simple al azar estratificado, considerando una prevalencia de 65\% (Manrique y Terán, 2002) con un nivel de confianza de 95\% y una precisión de 5\% (Daniel 1996). Se trabajó con 347 muestras de bovinos hembras y machos mayores a 6 meses, las que fueron estratificadas de acuerdo a la población de cada distrito (Cuadro 1). Para el análisis estadístico, las muestras fueron agrupadas en un grupo etáreo de 6 meses a 2 años y otro grupo mayor de dos años.

\section{Colección de Muestras}

Las muestras de sangre se obtuvieron por punción de la arteria coccígea o de la vena yugular. En el muestreo se utilizó el Formato de Vigilancia Activa del Servicio Nacional de Sanidad Agraria (SENASA) para registrar el productor, ubicación del predio, estado sanitario del hato, número de los animales muestreados, etc. Los sueros obtenidos fueron trasvasados en viales y transportados al Laboratorio de Virología de la Facultad de Medicina Veterinaria (FMV) de la Universidad Nacional Mayor de San Marcos (UNMSM), Lima.

\section{Detección de Anticuerpos}

La detección y titulación de los anticuerpos contra el VDVB se realizó mediante la técnica de neutralización viral utilizando como antígeno la cepa Singer, prototipo del biotipo cp y genotipo 1, del VDVB con un título de $10^{-5} \mathrm{DI}_{50} \mathrm{cc} / 50 \mu \mathrm{l}$, y monocapas celulares de cornete nasal de feto de bovino preparados en el Laboratorio de Virología de la FMV-UNMSM, como un sistema indicador y según el protocolo disponible en el Laboratorio de Virología (Rivera et al., 2002). Un suero fue considerado positivo a anticuerpos contra el VDVB cuando fue capaz de neutralizar el $100 \%$ de la capacidad infectante del virus en la monocapa celular (sin efecto citopático) y negativo a anticuerpos cuando no neutralizó el $100 \%$ de la capacidad infectante del virus en la monocapa celular (con efecto citopático). La prevalencia viral fue expresada en forma porcentual y con los intervalos de confianza del $95 \%$.

\section{Detección de Animales Portadores}

La detección de animales portadores (PI) se realizó en animales entre seis meses y dos años de edad por ser el grupo de riesgo, mediante el kit comercial de ELISA de captura (IDEXX, USA).

\section{Resultados}

El $47.8 \pm 0.1 \%(166 / 347)$ de muestras tuvieron anticuerpos neutralizantes contra el VDVB. Se encontró animales seroreactores en todos los distritos (Cuadro 1). No se detectaron animales PI. La prevalencia viral en animales de hasta dos años fue de $36.6 \%$ $(56 / 153)$ y la de animales mayores de dos años fue de $56.7 \%$ (110/194). El análisis mediante Chi Cuadrado indicó que hubo diferencia estadística $(p<0.05)$. La distribución de los títulos de anticuerpos contra el VDVB se muestra en el Cuadro 2.

Los datos consignados en el Formato de Vigilancia Activa del SENASA indicaron que 35 animales tuvieron historia de abortos y repeticiones del celo pero solo 22 de ellos (34.3\%) presentaron anticuerpos contra el VDVB.

\section{Discusión}

La presencia de anticuerpos contra el VDVB en el $47.8 \pm 0.1 \%$ de los animales muestreados sin historia de vacunación en la provincia de Melgar indica exposición de los animales al virus de campo; así mismo, los resultados indicaron que el virus se encuentra en al ganado bovino de todos los distritos de la provincia (Cuadro 1). La seroporevalencia viral fue mayor en animales de más de dos años lo que podría indicar la persistencia de los anticuerpos en el animal o posibilidades de reinfecciones por el VDVB. 
Cuadro 1. Seroprevalencia del virus de la diarrea viral bovina (VDVB) en bovinos mayores de seis meses de los nueve distritos de la provincia de Melgar, Puno

\begin{tabular}{lcccc}
\hline & & & \multicolumn{2}{c}{ Animales con anticuerpos contra } \\
Distritos & $\begin{array}{c}\text { Población bovina } \\
(\mathrm{n})\end{array}$ & $\begin{array}{c}\text { Muestras } \\
(\mathrm{n})\end{array}$ & & \multicolumn{2}{c}{ VDVB } \\
\cline { 4 - 5 } & & 66 & 19 & $\mathrm{~N}^{\circ}$ ? IC \\
\hline Nuñoa & 17,300 & 53 & 16 & $30.0 ? 0.1$ \\
Orurillo & 13,950 & 48 & 25 & $52.0 ? 0.1$ \\
Umachiri & 12,780 & 47 & 19 & $40.4 ? 0.1$ \\
Ayaviri & 12,560 & 40 & 28 & $70.0 ? 0.1$ \\
Santa Rosa & 10,610 & 38 & 25 & $66.0 ? 0.2$ \\
Macari & 10,030 & 19 & 3 & $15.8 ? 0.2$ \\
Antauta & 5,090 & 19 & 15 & $79.0 ? 0.2$ \\
Llalli & 5,080 & 17 & 16 & $94.1 ? 0.1$ \\
Cupi & 4,310 & 347 & 166 & $47.8 ? 0.1$ \\
\hline Total & 91,710 & & & \\
\hline
\end{tabular}

${ }^{1}$ Intervalo de Confianza del 95\%

Cuadro 2. Distribución de los títulos de anticuerpos contra el virus de la diarrea viral (VDVB) en bovinos mayores de seis meses de los nueve distritos de la provincia de Melgar, Puno

\begin{tabular}{lcccc}
\hline & \multicolumn{5}{c}{$\begin{array}{c}\text { Título de anticuerpos contra el VDVB } \\
\text { (inversa de la dilución) }\end{array}$} \\
\cline { 2 - 5 } Distritos & $2-8$ & $16-64$ & $128->256$ & Total de positivos \\
\hline Nuñoa & 6 & 8 & 5 & 19 \\
Orurillo & 5 & 9 & 2 & 16 \\
Umachiri & 8 & 16 & 1 & 25 \\
Ayaviri & 1 & 7 & 11 & 19 \\
Santa Rosa & 6 & 5 & 17 & 28 \\
Macari & 2 & 9 & 14 & 25 \\
Antauta & 0 & 0 & 3 & 3 \\
Llalli & 2 & 5 & 8 & 15 \\
Cupi & 1 & 6 & 9 & 16 \\
\hline Total & 31 & 65 & 70 & 166 \\
\hline
\end{tabular}


La presencia del virus en esta zona altoandina podría deberse a la introducción de reproductores y al movimiento irrestricto de los animales dentro de la zona. Otro factor de importancia corresponde a las ferias ganaderas donde concurren animales de todo tipo, edad y condición sanitaria constituyendo un potencial fuente de contagio; ya que en estas ferias se realiza la compra-venta de animales, no solo para el consumo sino también para crianza, de modo que son llevados a las respectivas zonas de crianza constituyendo un riesgo para los demás animales del hato o rebaño.

Cuando el virus ingresa a un hato de crianza extensiva o semiextensiva constituido por pocos animales, usualmente todos se infectan, con o sin consecuencias clínicas como abortos, nacimiento de terneros PI, etc., pero seroconvierten y quedan protegidos contra reinfecciones, siendo la infección en estos casos autolimitante (Ståhl et al., 2008); a diferencia del sistema de crianza intensivo como en la cuenca lechera de Lima, donde, el virus persiste en el hato a menos que se establezca un adecuado sistema de control y bioseguridad (Aguilar et al., 2006).

En estudios realizados en bovinos criollos de Ayacucho (Rivera et al., 2001) y Cusco (Alvarez et al., 2002; Cabello et al., 2006) se encontró prevalencias superiores a $70 \%$. Al parecer los animales criollos son altamente susceptibles, posiblemente debido al estrés por fallas nutricionales e infecciones parasitarias, pero los efectos del virus podrían pasar desapercibidos o ser confundidos con otros problemas sanitarios. El VEF, que afecta mayormente al ovino, puede afectar al bovino si comparten pasturas o corrales, como el caso de animales en la provincia de Melgar, y los anticuerpos no pueden ser discriminados en el laboratorio por la relación antigénica entre ambos virus.

La seroprevalencia viral tuvo un rango de 15.8 a 94.1 (Cuadro 1). Los criadores de los distritos de Cupi, Llalli, Santa Rosa, Macari y Umachiri, donde se detectó el mayor nú- mero de animales seropositivos, adquieren reproductores en las ferias ganaderas de la región, aunque también utilizan la inseminación artificial para mejorar la calidad genética de su ganado. El uso de tecnología moderna como la inseminación artificial tiene ventajas, pues enfermedades como la campylobacteriosis y trichomoniasis, cuyos agentes causales son transmitidos durante la monta, pueden ser eliminados; pero también a través de esta tecnología se puede transmitir enfermedades virales como el VDVB si el semen proviene de toros que no son libres del virus. Por otro lado, los animales del distrito de Antauta presentaron la menor prevalencia del VDVB $(15.8 \pm 0.16)$ ya que en el distrito predomina la crianza ovina. La baja prevalencia viral en estos animales sugiere que la infección es mayormente por el VDVB y la transmisión interespecie de VEF a bovinos no es frecuente en este distrito.

Algunos criadores manifestaron durante el muestreo la ocurrencia de problemas respiratorios (sobre todo en terneros) y reproductivos como una alta frecuencia de retorno al celo; sin embargo, solo un tercio de estos animales tuvieron anticuerpos contra el VDVB. Como los criadores no llevan un registro de la historia de sus animales es difícil asociar el problema reproductivo al VDVB, pero tampoco debería descartarse el efecto del VDVB, sobre todo cuando el virus ingresa por primera vez al hato (McGowan y Kirkland, 1995); sin embargo, es posible que el VDVB, por su efecto inmunodepresor, sea un componente del complejo respiratorio que se observa en los terneros (Brownlie, 1991; Rivera et al., 1994; Brodersen y Kelling, 1998; Rivera, 2001).

Los títulos de anticuerpos neutralizantes estuvieron en el rango de 2 a > 256 (Cuadro 2). En un mismo hato se detectaron diversos niveles de anticuerpos y también animales sin anticuerpos. Los perfiles de anticuerpos, denominados de modo arbitrario como títulos bajos (2-8) intermedios (16-64) y altos (128$>256$ ) indican actividad viral en los animales de la zona debido a factores diversos como 
el estrés, ingreso de animales infectados, transmisión interespecie e incluso la presencia de animales PI. Cuando el VDVB ingresa a un hato susceptible, puede ocasionar una infección aguda, moderada o de tipo subclínica, pero los animales desarrollan una sólida inmunidad humoral en una a tres semanas post infección alcanzando niveles altos de anticuerpos en 10-12 semanas, hasta alcanzar una meseta que perdura mucho tiempo antes de desaparecer lentamente (Fredriksen et al., 1999). El 39 y $42 \%$ de los animales seropositivos tuvieron títulos entre 16 a 64 y entre 128->256, respectivamente (Cuadro 2), sugiriendo que podrían corresponder a infecciones recientes o a la meseta de anticuerpos.

El mayor número de animales seropositivos del presente estudio tuvo títulos similares a un reporte de Parinacochas, Ayacucho (Rivera et al., 2001). Se indica que cuando las prevalencias del VDVB son superiores a $70 \%$ hay la posibilidad de tener animales PI (Houe, 1995, 2003). Este concepto ha sido demostrado en hatos pequeños de crianza semi-intensivo (Rivera et al., 2002; Huamán et al., 2007). En el presente estudio no se detectaron animales PI, posiblemente porque estos animales, en caso de aparecer, morirían tempranamente por problemas respiratorios o gastrointestinales.

\section{Literatura Citada}

1. Alvarez S, Rivera H, Pezo D, García $W$. 2002. Detección de anticuerpos contra pestivirus en rumiantes de una comunidad campesina de la provincia de Canchis-Cusco. Rev Inv Vet, Perú 13(1): 46-51.

2. Aguilar R, Benito A, Rivera H. 2006. Seroprevalencia del virus de la diarrea viral bovina en ganado lechero de crianza intensiva del valle de Lima. Rev Inv Vet, Perú 17: 148-153.

3. Baker JC. 1995. The clinical manifestations of bovine viral diarrhea infection. Vet Clin N Am: Food Anim Pract 11: 425-445.
4. Brodersen BW, Kelling CL. 1998. Effect of concurrent experimentally induced bovine respiratory syncytial virus and bovine viral diarrhea virus infections on respiratory tract and enteric diseases in calves. Am J Vet Res 59: 1423-1430.

5. Brownlie J. 1991. The pathways for bovine virus diarrhea virus biotypes in the pathogenesis of disease. Arch Virol 3 (Suppl): 79-96.

6. Brownlie J, Hooper LB, Thompson I, Collins ME. 1998. Maternal recognition of fetal infection with bovine virus diarrhea virus (BVDV) - the bovine pestivirus. Clin Diagn Virol 10: 141-150.

7. Cabello K, Quipe R, Rivera H. 2006. Frecuencia de los virus Parainfluenza 3, respiratorio sincitial, y diarrea viral bovina en un rebaño mixto de una comunidad campesina de Cusco. Rev Inv Vet, Perú 17(2): 167-172.

8. Contreras G, Ståhl K, Arana C, Rivera H. 2000. Anticuerpos contra el virus de la Diarrea Viral Bovina en muestras de leche de bovinos del valle de Mantaro (Jauja, Concepción y Huancayo). Rev Inv Vet, Perú 11(1): 1-10.

9. Daniel WW. 1996. Bioestadística: base para el análisis de las ciencias de la salud. $5^{\text {ta }}$ ed. México DF: Ed. Limusa. 878 p.

10. Fredriksen B, Sandvick T, Loken T, Odegard SA. 1999. Level and duration antibodies in cattle infected experimentally and naturally with bovine virus diarrhea virus. Vet Rec 144: 111114.

11. Houe H. 1995. Epidemiology of bovine viral diarrhea virus. Vet Clin N Am: Food Anim Pract 11(3): 521-547.

12. Houe H. 1999. Epidemiological features and economical importance of bovine viral diarrhoea virus (BVDV) infections. Vet Microbiol 64: 89-107.

13. Houe H. 2003. Economic impact of BVDV infection in dairies. Biologicals 31: 137-143.

14. Huamán JC, Rivera H, Araínga R, Gavidia C, Manchego A. 2007. Diarrea viral bovina y animales portadores 
del virus en hatos productores de leche de la irrigación de Majes, Arequipa. Rev Inv Vet, Perú 18: 141-149.

15. [MINAG-OIA] Ministerio de Agricultura, Oficina de Información AgrariaPuno. 2003. Archivos de producción Pecuaria. Puno: MINAG. 15 p.

16. McGowan MR, Kirkland PD. 1995. Early reproductive loss due to bovine pestivirus infection. Br Vet J 151: 263269.

17. Rivera H. 2001. Etiología infecciosa del aborto bovino. Rev Inv Vet, Perú 12(2): 117-122.

18. Rivera H, Huamán K, Benito A, Díaz $A$, Arana C. 2002. Prevalencia del virus de la diarrea viral bovina y animales portadores del virus en un hato lechero del valle del Mantaro. Rev Acad Per Cienc Vet 3: 1-7.

19. Rivera H, Manchego A, Sandoval N, Flores E. 1994. Complejo respiratorio bovino en terneros del valle de Lima. Rev Inv Pec, IVITA 7 (1): 35-38.

20. Rivera H, Valdivia L, Benito A. 2001. Diarrea viral en bovinos lecheros de crianza semi extensiva de la Provincia de Parinacochas, Ayacucho. Rev Inv Vet, Perú (Supl 1): 380-381.

21. Ståhl H, Lindberg A, Rivera H, Ortiz C, Moreno-López J. 2008. Selfclearance from BVDV infections- A frequent finding in dairy herds in an endemically infected region in Peru. Prev Vet Med 83: 285-296.

22. Wengler G. 1991. Family Flaviviridae. Arch Virol (Suppl) 2: 228-229. 